\title{
RELATIVE AGE EFFECT IN JUNIOR TENNIS (MALE)
}

\author{
Adrián Agricola*, Jiří Zháněl, Ondřej Hubáček
}

Faculty of Physical Culture, Palacký University, Olomouc, Czech Republic

Submitted in January, 2013

BACKGROUND: The issues of the age effect (the theory of the age influence) have been shown in sport sciences since the 1980s. The theory of age effect works on the assumption that athletes born in the beginning of a calendar year are, particularly in children's and junior age, more successful than athletes born in the end of the year. This fact has been proved by a number of research studies, mainly in ice hockey, soccer, and tennis but also in other sports.

OBJECTIVE: The submitted contribution is aimed at verifying of the age effect in junior tennis. The research objective was to find out the distribution of birth date frequencies in a population of tennis players' in individual months, quarters, and half-years in the observed period 2007-2011 and to check the significance of differences.

METHODS: The research was conducted on male tennis players aged 13-14 $(N=239)$, participants of the World Junior Tennis Finals. From the methodological point of view, it was an intentional selection. The birth dates of individual tennis players were taken from official materials of the ITF, the research data were processed using Microsoft Excel. The personal data were processed with the approval of players and the hosting organization (ITF).

RESULTS: Testing of the hypothesis on the significance of differences in the distribution of frequencies between individual quarters (Q1-Q4) has proved statistically relevant differences between Q1 and Q3, Q1 and Q4, Q2 and $\mathrm{Q}$ 3, and Q2 and Q4; a statistically relevant difference has been also found in the distribution of frequencies between the first and second half of the year. On the basis of the results of the presented research, the age effect in the studied population of junior male tennis players can be regarded as significant.

CONCLUSIONS: The results of the analysis of the research data confirm the conclusions of similar studies in other sports and prove that in the population of elite junior players, participants of WJTF 2007-2011, there is a pronounced dominance of players born in the first and second quarters, i.e. in the first half-year. The mentioned conclusions show the necessity of reflecting the age effect in sports practice as it can influence sports performance, especially at the junior level.

Keywords: Date of birth, age, tennis, male players, World Junior Tennis Finals.

\section{INTRODUCTION}

The term "age effect", or the relative age effect, has been shown in sport sciences since the1980s. However, as later proven by evidence, a considerable research boom in this area has been shown only in the last decade (Delormé, Boiché, Raspaud, 2010; Lames, Augste, Dreckmann, Görsdorf, \& Schimanski, 2008).

Research studies on the age effect topic are presented in prestigious world scientific magazines (e.g. Canadian Journal of Behavioral Science, Journal of Sports Science and Medicine, European Journal of Sport Science, Journal of Sport Science, Sociology of Sport Journal) and the research results point out the importance of the age effect for sports practice. In the

\footnotetext{
* Address for correspondence: Adrián Agricola, Department of Natural Sciences in Kinanthropology, Faculty of Physical Culture, Palacký University, tř. Míru 115, 77111 Olomouc, Czech Republic. E-mail: adrian.agricola@gmail.com
}

presented paper, we want to contribute to the clarification of the term "age effect" (this issue has not been published in Czech kinanthropological papers yet) and to analyze its influence in tennis using the particular research of leading world junior male tennis players (participants of the World Junior Tennis Finals in the years 2007-2011).

The term (relative) age effect means the deviation of distribution of the selected athletes' birth dates from the normal distribution in the population. This means that the birth dates of selected groups of athletes are not distributed normally, i.e. approximately evenly throughout the whole year. On the contrary, the dates accumulate at the beginning of the chosen period of time when relatively older individuals are represented in the chosen sample more often than relatively younger individuals (Lames, Augste, Dreckmann, Görsdorf, \& Schimanski, 2008, 2009). The athletes born in the beginning of a calendar year have a certain advantage when compared to the athletes born in the end of the 
same year because they are older by the number of month separating their birth dates. The age difference can be practically up to 12 months, which, for example, is $10 \%$ of ten year old children's lives. In prepubertal period, this shows in the advantage of conditioning, morphological, and mental prerequisites, but also in greater experience - in sports and life as well - which can bring performance advantages too (Lames et al., 2009). These factors can have great influence on increasing performance in comparison to individuals born in later month. Then in practice, older individuals are often referred as "more talented", they receive special attention in the training process, which increases their performance and they are often included - because of their maturity - in higher age categories. The result of this is that they play better competitions of higher quality and that is why they have greater chances to be successful in the long term. However, after puberty, the level of age related prerequisites levels off and later born children "catch up" with those born earlier (Del Campo, Vicedo, Villora, \& Jordan, 2010; Lames et al., 2008). Therefore in sports practice, it is important to realize the age effect and to eliminate its influence particularly when identifying talents and judging the level of performance prerequisites.

A number of authors (Barnsley \& Thompson, 1988; Helsen, Starkes, \& Van Winckel, 2000; Simmons \& Paull, 2001) believe that the age effect is also shown in the mental area because there is a great probability that younger athletes lack inner motivation as they are less convinced of the possibility of success when compared with their older, often more successful peers. Frequently, they also meet a lack of external motivation, which includes insufficient support from coaches or parents. The psychological component of more successful individuals is supported also by the so-called self-strengthening process (Lames et al., 2008). It appears after first successes (e.g. after important selections) and has a motivating effect when overcoming further obstacles.

Thus, the age effect is a problem that applies to sports selections at various levels and to various categories, both children's and junior as well as senior categories. In a number of sports, an important factor influencing sports performance is the body height and weight, which is connected with a higher level of physical condition (Helsen et al., 2005).

The strong age effect can be observed mainly in sports where a high level of physical condition is an important performance prerequisite, i.e. in sports where an above-average body height, weight, and strength are an advantage, for example in ice hockey. In the area of competitive sport, the age effect was first studied in ice hockey where it was found that in junior leagues as well as in the NHL, the frequency of distribution of players born in respective months of the year decreased in the direction from January to December. The level of strength, speed or coordination, i.e. abilities specific for ice hockey players, according to Barnsley, Thompson, and Barnsley (1985), strongly correlates with the age of an individual. According to the findings of Baxter-Jones (1995), the age effect should then be minimal (or zero) in sports where, on the contrary, the "later" maturity of the athlete is an advantage. So, a strong age effect has been found in female tennis players but none in female gymnasts. According to Lames et al. (2009), it is worth to mention also the studies of other collective sports, e.g. handball, cricket, American football, baseball, volleyball and soccer. Del Campo et al. (2010) point out that the age effect is shown also in individual sports - a number of studies have been made in swimming or tennis. Edgar and O'Donoghue (2005) have come to the conclusion that in tennis, $58.9 \%$ of male and female players who reached the top level in their career were born in the first six months of the year.

The aforesaid findings show that the age effect is present in selection of talents in most sports and it influences this selection considerably. The greatest influence has been found in collective sports, especially in soccer and ice hockey. Because these are the most widespread collective sports, research studies have been made in various parts of the world. And as the age effect appears both on the northern and southern hemispheres, the climatic and regional differences have been excluded.

\section{METHODOLOGY}

Research purpose, research objectives, and hypotheses The purpose of the research was to find out, if it is possible to prove the age effect's influence in a population of junior tennis players who took part in the world championships in 14 year old category (WJTF) in the years from 2007-2011.

\section{Research objectives}

1. Finding out the distribution of birth date frequencies in calendar months and quarters of players' subpopulations in individual years of the observed period (2007-2011).

2. Finding out the distribution of birth date frequencies of the players' population in individual months, quarters, and half-years of the whole observed period (WJTF 2007-2011).

To verify the research intent, two hypotheses in the form of alternative hypotheses were formulated, based on the synthesis of findings and with regard to the normal distribution of birth date frequencies in the normal population, as the null hypothesis on insignificant dif- 
ferences in distribution of birth date frequencies in individual quarters or half-years is not justifiable because of the published facts on the found age effect influence in junior athletes.

\section{Hypotheses}

$\mathrm{H} 1_{1}$ : the differences in percentage representation of birth dates frequencies of tennis players among individual quarters are statistically significant.

$\mathrm{H}_{2}$ : the differences in percentage representation birth dates frequencies of tennis player between the first and second half-years are statistically significant.

\section{Research methodology}

The research was conducted during the annual World Junior Tennis Finals (WJTF) organized by the International Tennis Federation (ITF). The World Championship consists of teams of male and female tennis players up to 14 years of age and has taken place in Prostějov since 1999. Individual teams have three members, male and female tennis players successively play two singles and one doubles match, first in drawn four-member groups and then for total placing. Every year, the participants of the tournament are always the 16 best boys' and 16 girls' teams from all over the world; therefore, they are the best world male and female players in the category of 14 year olds and younger.

The research was conducted between the years 2007-2011 and it was aimed at a research population of boys, totaling 239 players aged 13-14 (48 players in each year with 47 players in 2010); from the methodological point of view, it was an intentional selection. The birth dates of individual tennis players were taken from official materials of the ITF, the research data were processed using Microsoft Excel. In order to test the hypotheses on the significance of differences in frequencies expressed in percentages, we used a t-test modification for percentages (Kovář \& Blahuš, 1989). This $t$-test is sometimes also marked as asymptotically valid $z$-test. The personal data were processed with the approval of players and the hosting organization (ITF).

\section{RESULTS}

For the purpose of judging the research intent and achieving the research objectives, the research data were statistically processed in the form of tables. Table 1 shows the total number of players playing in individual years 2007-2011 at the WJTF and their months of birth (M). The months are grouped by three into individual quarters (Q). The percentage representation of each quarter has been calculated from the total number of players in the given year.

Table 1 shows that most players born in the first quarter were at the tournament in 2011 (45.8\%) and least in $2008(29.2 \%)$. The number of players born in the first half-year (the first two quarters) was more than $65 \%$ in 2008 and 2009 (identically 68.8\%) and even more than $70 \%$ in 2007,2010 , and $2011(75.1 \%$,

Table 1

The survey of the distribution of players' birth dates frequencies in individual years and in the whole observed period (2007-2011)

\begin{tabular}{|c|c|c|c|c|c|c|c|c|c|c|c|c|c|c|c|c|c|c|}
\hline \multirow{2}{*}{ Month } & \multicolumn{3}{|c|}{2007} & \multicolumn{3}{|c|}{2008} & \multicolumn{3}{|c|}{2009} & \multicolumn{3}{|c|}{2010} & \multicolumn{3}{|c|}{2011} & \multicolumn{3}{|c|}{$2007-2011$} \\
\hline & M & Q & $\%$ & M & Q & $\%$ & M & Q & $\%$ & $\mathrm{M}$ & $\mathrm{Q}$ & $\%$ & M & Q & $\%$ & M & Q & $\%$ \\
\hline January & 7 & & & 7 & & & 6 & & & 5 & & & 9 & & & 34 & & \\
\hline February & 5 & 21 & 43.8 & 7 & 14 & 29.2 & 7 & 18 & 37.6 & 10 & 18 & 38.3 & 5 & 22 & 45.8 & 34 & 93 & 38.9 \\
\hline March & 9 & & & 0 & & & 5 & & & 3 & & & 8 & & & 25 & & \\
\hline April & 7 & & & 9 & & & 8 & & & 5 & & & 7 & & & 36 & & \\
\hline May & 5 & 15 & 31.3 & 6 & 19 & 39.6 & 5 & 15 & 31.2 & 7 & 16 & 34.0 & 5 & 17 & 35.5 & 28 & 82 & 34.3 \\
\hline June & 3 & & & 4 & & & 2 & & & 4 & & & 5 & & & 18 & & \\
\hline July & 5 & & & 5 & & & 4 & & & 0 & & & 1 & & & 15 & & \\
\hline August & 2 & 8 & 16.6 & 3 & 9 & 18.7 & 1 & 10 & 20.8 & 4 & 6 & 12.8 & 1 & 5 & 10.4 & 11 & 38 & 15.9 \\
\hline September & 1 & & & 1 & & & 5 & & & 2 & & & 3 & & & 12 & & \\
\hline October & 1 & & & 4 & & & 2 & & & 4 & & & 2 & & & 13 & & \\
\hline November & 2 & 4 & 8.3 & 1 & 6 & 12.5 & 2 & 5 & 10.4 & 2 & 7 & 14.9 & 2 & 4 & 8.3 & 9 & 26 & 10.9 \\
\hline December & 1 & & & 1 & & & 1 & & & 1 & & & 0 & & & 4 & & \\
\hline Total & 48 & & 100 & 48 & & 100 & 48 & & 100 & 47 & & 100 & 48 & & 100 & 239 & & 100 \\
\hline
\end{tabular}

Note. $\mathrm{M}=$ month, $\mathrm{Q}=$ quarter. 
$72.3 \%, 81.3 \%$, respectively). The distribution of birth dates frequencies in individual months, quarters or half-years will be analyzed and statistically verified in further parts of the paper.

The total number of players' birth dates in individual months and quarters is shown during the whole observed period 2007-2011; the percentage representation of each quarter has been calculated from the total number of players $(N=239)$.

The summary of results has proved that most players were born in the first quarter $(38.9 \%)$, then $34.3 \%$ in the second quarter, $15.9 \%$ in the third one, while only $10.9 \%$ in the last one. This means that $73.2 \%$ of players were born in the first half-year, i.e. almost $3 / 4$ of all participants of the WJTF in 2007-2011. Based on the shown values, it is possible to conclude a significant influence of the age effect in elite young male tennis players. In order to test the hypothesis on the significance of differences in frequencies between individual quarters and between particular half-years in 2007-2011 expressed in percentages, we used a t-test modification for percentages (Kovář \& Blahuš, 1989). The alternative hypothesis $\mathrm{H}_{1}$ expressed an assumption that the differences in the distribution of the tennis players' birth dates between individual quarters are statistically significant.

The results in Table 2 show that in case of judging the significance of differences in frequencies of players represented in individual quarters, there has been found no statistically significant difference between Q1 and Q2 $\left(0.86<1.96=\mathrm{t}_{\mathrm{Tab} .05}\right.$ or $\left.2.58=\mathrm{t}_{\mathrm{Tab} .01}\right)$ as well as between the quarters Q3 and Q4 $\left(0.57<1.96=\mathrm{t}_{\text {Tab.05 }}\right.$ or $\left.2.58=\mathrm{t}_{\text {Tab .01 }}\right)$, so the hypothesis $\mathrm{H}_{1}$ has been rejected.

On the contrary, a statistically significant difference has been found between the quarters Q1 and Q3 $\left(3.72>1.96=\mathrm{t}_{\text {Tab. } 05}\right.$ or $\left.2.58=\mathrm{t}_{\mathrm{Tab} .01}\right)$, further on between the quarters Q1 and Q4 $\left(4.32>1.96=\mathrm{t}_{\mathrm{Tab} .05}\right.$ or $2.58=$ $\left.\mathrm{t}_{\text {Tab.01 }}\right)$, the quarters Q2 and Q3 (2.85>1.96 = $\mathrm{t}_{\text {Tab .05 }}$ or $\left.2.58=\mathrm{t}_{\mathrm{Tab} .01}\right)$ and also between the quarters Q2 and Q4 $\left(3.44>1.96=\mathrm{t}_{\mathrm{Tab} .05}\right.$ or $\left.2.58=\mathrm{t}_{\mathrm{Tab} .01}\right)$; so, in these cases, the hypothesis $\mathrm{H}_{1}$ has not been rejected.

Table 2

Testing the hypothesis on the significance of differences between individual quarters

\begin{tabular}{lcccccc}
\hline Quarter & Quantity & $\%$ & Q1 & Q2 & Q3 & Q4 \\
\hline Q1 & 93 & 38.9 & & R & N & N \\
Q2 & 82 & 34.3 & R & & N & N \\
Q3 & 38 & 15.9 & N & N & & R \\
Q4 & 26 & 10.9 & N & N & R & \\
Total & 239 & 100 & & & & \\
\hline
\end{tabular}

Note. $\mathrm{R}=$ hypothesis $\mathrm{H} 1_{1}$ has been rejected. $\mathrm{N}=$ hypothesis $\mathrm{H} 1_{1}$ cannot be rejected.
From the total number of 239 players, more than two thirds $(73.2 \%)$ were born in the first half-year and only less than a third (26.8\%) in the second half-year. Testing of the hypothesis on the significance of differences between individual half-years in 2007-2011 has proved a statistically significant difference $\left(10.1>1.96=\mathrm{t}_{\mathrm{Tab} .05}\right.$ or $\left.2.58=\mathrm{t}_{\mathrm{Tab} .01}\right)$; so, the hypothesis has not been rejected.

The found results induce another research problem - finding potential presence and influence of the age effect in adult elite world players, i.e. comparing the situation of junior and adult tennis players.

\section{DISCUSSION}

As the overview of knowledge mentioned in the introduction shows, most authors are dealing with issues of age effect in football and ice hockey. Bäumler (2000) has examined 3,000 elite players of the German football league and found out that $56 \%$ of surveyed players were born in the first half of the year. Del Campo et al. (2010) focused his research on the impact of age effect influence on Spanish youth soccer in under - 11, 13, 15 and 18 categories. The amount of players born in first half of the year represented more than $40 \%$ in each mentioned category. Helsen et al. (2005) studied influence of the age of men and women in national U15 and U18 youth selection in ten European countries over the years 1999-2000 and in U16, U18 and U21 (men) and U18 (women) selections that attended youth international tournaments. Results showed clear link between the date of birth and number of members of a selection. Research on age effect in ice hockey was conducted by Barnsley, Thomson, and Barnsley (1985), who studied junior league players (age 18-20), national selections and NHL. Results of this study show that 4-times more players were born in the first quarter than in the remaining months. Musch and Grondin (2001) indicate that out of all NHL players playing in this league at the end of the last century $40 \%$ were born in the first quar-

Table 3

Testing the hypothesis on the significance of differences between individual half-years

\begin{tabular}{ccccc}
\hline Half-year & Quantity & $\%$ & $t$ & $\mathrm{H}$ \\
\hline $1^{\text {st }}$ half-year & 175 & 73.2 & $10.1^{*}$ & $\mathrm{~N}$ \\
$2^{\text {nd }}$ half-year & 64 & 26.8 & & \\
Total & 239 & 100 & & \\
\hline
\end{tabular}

Note. $\mathrm{N}=$ hypothesis $\mathrm{H} 2_{1}$ cannot be rejected.

* statistically significant difference. 
ter, $30 \%$ in the second, $20 \%$ in the third and $10 \%$ in the last quarter of a year. All of the mentioned facts suggest that age effect is a real problem not limited only to youth systems, a suggestion true for both local and international levels. Rodenberg (2010), who studied the age effect in tennis, in his paper on the ITA (Intercollegiate Tennis Association) website, writes that he heard many times during his active junior tennis career how players and parents spoke about "good or bad birth date". As he mentions further, the good of bad birth date follows from obsolete principles of talent selection where the identification of a talent is based only on the selection by somatotype, for example.

Therefore, sports organizations and clubs should try to use the latest findings on talent identification, which are not based only on the area of the mentioned selection by somatotype or relative maturity of an individual. So, parents, players, and coaches should be sufficiently informed that the full potential of an athlete does is not clear until the end of his/her maturing. Lames et al. (2009) mention an important fact from the area of German soccer where the selections for individual categories are mostly made in a young age around the $12^{\text {th }}$ year of athlete's life while the athlete's full maturity often comes as late as in his/her $21^{\text {st }}$ year of age. However, at this age, the player cannot expect any support of training centers or other organizations as it is supposed that he/she should be in a professional club at this age.

In English professional literature, the issues of age effect are often connected with the term "cut-off date". It is actually a selection date when individual agegroups are divided. In some sports or competitions, it is the last day of the calendar year, in others the 1st September, for example. Musch and Hay (1999) state that it does not matter, on which day or month the cuttoff date falls. The majority of young athletes who were included into the highest performance classes or were members of representative selections were born right in the first quarter of the calendar year or in the first quarter of the year after the cutt-off date. The situation was reverse with individuals who were born right before this date; those who were born in the last quarter of the year (or in the last quarter before the cut-off date) were represented in individual teams or selections in the least. The closer to this date an individual is born, the greater the advantage following from the age effect. This opinion has been confirmed also by Edgar and O’Donoghue (2005), Helsen et al. (2000), Simmons and Paull (2001). However, it is necessary to add that research studies have proved that the age effect gradually disappears during the ontogenetic development and that this influence was pronounced especially in the research of boys' categories and was not so obvious in girls (Cobley et al., 2009; Lames, 2008). There are several explanations for that, one of the most important being the difference between the end of girls' and boys' puberty. As this period often ends for girls before sports selection (children's and junior selections), the effect is not so pronounced. Besides, when the female variant of a sport is similarly physically demanding as the male one, then the advantage consisting in earlier maturing is lower. If the girls' involvement in a sport is smaller, as a consequence, the selection pressure decreases and a smaller age effect is expected (Lames, 2008).

Concerning tennis, we can compare our findings to similar research conducted by Edgar and O'Donoghue among young tennis players $(N=476)$ and published in the prestigious Journal of Sport Sciences (2005). This study similarly shows higher representation of boys born in the first quarter (33.0\%) although the value is lower than one presented in our research (38.9\%). Amount of natality of particular quarters gradually decreases $(33.3 \%-29.9 \%-21.5 \%-15.1 \%)$ over the year likewise in our research findings $(38.9 \%-34.3 \%$ $-15.9 \%-10.9 \%$ ). Similarly, differences were observed among particular quarters - most notable ones between $2^{\text {nd }}$ and $3^{\text {rd }}$ quarter among boys $(8.4 \%)$. Similarly in our study where this difference (18.4\%) was the highest.

Currently, there are just a few scientific studies on age effect in individual sports and especially in tennis. The presented study offers new information on age effect influence of elite junior tennis players, the best players of the world in this particular age category.

The fact that the research was conducted on a long-term basis we consider to be the strongest point (2007-2011), and eliminates possible year to year differences. A certain study limitation lies in possible application of results, because players in this age category are already expected to achieve the best possible results regardless of their future development (so called burnout syndrome).

According to a number of authors it is obvious that age effect may influence juniors especially concerning their somatic and physical prerequisites and often their results. These advantages are not limited only to somatic and physical areas but to mental area as well. It is a well-known fact and issue that in junior period "the best" athletes are logically preferred and that their performance may be well influenced by their age. In relation to the aforementioned findings, it would be advisable to try to eliminate this influence.

It would be suitable to take the aforementioned findings into consideration when selecting talents and choosing athletes for national teams. It is a known fact that the age effect can influence particularly the level of somatic and condition prerequisites in junior age, and thus often sports results too. It is not only a matter of advantages in the area of somatic and condition 
characteristics but also of the mental aspect. In sports practice, the fact and also a problem is that at the junior level, the "best" athletes are logically preferred, i.e. those whose performance can be influenced by the age effect. When considering the above mentioned findings, eliminating this influence in practice would be suitable.

\section{CONCLUSIONS}

The results of the analysis of the research data confirm the conclusions of similar studies in other sports and prove that in the population of elite junior players, participants of WJTF 2007-2011, there is a pronounced dominance of players born in the first and second quarters, i.e. in the first half-year. The testing of the hypotheses on the significance of differences in the distribution of frequencies between individual quarters (Q1-Q4) has proved statistically significant differences between Q1 and Q3, Q1 and Q4, Q2 and Q3, and Q2 and $\mathrm{Q} 4$, so the hypothesis $\mathrm{H}_{1}$ has not been rejected; statistically insignificant differences have been found between Q1 and Q2, and Q3 and Q4; in these cases, the hypothesis $\mathrm{H}_{1}$ has been rejected. A statistically significant difference has been proved in the distribution of frequencies between the first and second half-years, therefore hypothesis $\mathrm{H}_{2}$, has not been rejected. In view of the results of the presented research, the influence of the age effect in the examined population of junior male tennis players can be considered significant.

\section{REFERENCES}

Bäumler, G. (2000). The relative age effect in soccer and its interaction with chronological age. Sportonomics, 6(1), 25-30.

Barnsley, R. H., \& Thompson, A. H. (1988). Birthdate and success in minor hockey: The key to the NHL. Canadian Journal of Behavioral Science, 20(2), 167-176.

Barnsley, R. H., Thompson, A. H., \& Barnsley, P. E. (1985). Hockey success and birth-date: The relative age effect. Journal of the Canadian Association for Health, Physical Education, and Recreation, 51, 23-28.

Baxter-Jones, A. D. (1995). Growth and development of young athletes. should competition levels be age related? Sports Medicine, 20(2), 59-64.

Cobley, S., Baker, J., Wattie, N., \& McKenna, J. M. (2009). Annual age grouping and athlete development: A meta-analytical review of relative age effects in sport. Sports Medicine, 39(3), 235-256.

Del Campo, D. G., Vicedo, J. C., Villora, S. G., \& Jordan, O. R. (2010). The relative age effect in youth soccer players from Spain. Journal of Sports Science and Medicine, 9(2), 190-198.

Delormé, N., Boiché, J., \& Raspaud, M. (2010). Relative sports effect in elite sports: Methodological bias or real discrimination? European Journal of Sport Science, 10(2),91-96.

Edgar, S., \& O’Donoghue, P. (2005). Season of birth distribution of elite tennis players. Journal of Sports Sciences, 23(10), 1013-1020.

Helsen, W. F., Starkes, J. L., \& Van Winckel, J. (2000). Effect of a change in selection year on success in male soccer players. American Journal of Human Biology, 12(6), 729-735.

Helsen, W. F., Van Winckel, J., \& Williams, M. A. (2005). The relative age effect in youth soccer across Europe. Journal of Sports Sciences, 23(6), 629-636.

Hohmann, A., Lames, M., \& Letzelter, M. (2010). Úvod do sportovního tréninku (T. Studený, Trans.). Prostějov: Sport a věda. (Original work published 2007).

Kovář, R., \& Blahuš, P. (1989). Aplikace vybraných statistických metod v antropomotorice. Praha: Státní pedagogické nakladatelství.

Lames, M., Augste, C., Dreckmann, C., Görsdorf, K., \& Schimanski, M. (2008). Der "Relative Age Effect” (RAE): Neue Hausaufgaben für den Sport. Leistungssport, 38(6), 4-9.

Lames, M., Augste, C., Dreckmann, C., Görsdorf, K., \& Schimanski, M. (2009). The relative age effect in German youth sports: Football, handball and ice-hockey. E-Journal "Bewegung und Training". Retrieved from www.sport.uni-augsburg. de/.../050lames/R...HS.../RAE_submitted.doc

Musch, J., \& Grondin, S. (2001). Unequal competition as an impediment to personal development: A review of the relative age effect in sport. Developmental Review, 21(2), 147-167.

Musch, J., \& Hay, R. (1999). The relative age effect in soccer: Cross-cultural evidence for a systematic discrimination against children born late in the competition year. Sociology of Sport Journal, 16(1), 54-64.

Puhani, P. A., \& Weber, A. M. (2007). Persistence of the school entry age effect in a system of flexible tracking. St. Gallen: University of St. Gallen.

Rodenberg, R. M. (2010). Is there (still) relative age effect in tennis? Intercollegiate Tennis Association. Retrieved from http://www.itatennis.com/Page3508. aspx

Schorer, J., Baker, J., Büsch, D.,Wilhelm, A., \& Pabst, J. (2009). Relative age, talent identification and youth skill development: Do relatively younger athletes have superior technical skills? Talent Development and Excellence, 1(1), 45-56. 
Simmons, C., \& Paull, G. C. (2001). Season of birth bias in association football. Journal of Sports Sciences, 19(9), 677-686.

\section{„AGE EFFECT“ V JUNIORSKÉM TENISU (JUNIOŘI) \\ (Souhrn anglického textu)}

VÝCHODISKA: Problematika „age effect“ (teorie vlivu věku) se ve sportovních vědách objevuje od osmdesátých let minulého století a vychází z předpokladu, že sportovci narození na začátku kalendářního roku jsou hlavně v žákovském a juniorském věku úspěšnější oproti sportovcům narozeným koncem roku. Tato skutečnost je prokázána řadou výzkumů v hokeji, fotbale, tenise ale i v jiných sportech.

CÍLE: Předložený příspěvek je zaměřen na ověrení vlivu „age effect“ v juniorském tenise. Cílem výzkumu bylo zjistit rozložení četností narození souborů tenistů $\mathrm{v}$ jednotlivých měsících, čtvrtletích a pololetích ve sledovaném období 2007-2011 a ověřit významnost rozdílů.

METODA: Výzkum byl realizován u tenistů ve věku 13-14 let $(N=239)$, účastníků World Junior Tennis Finals. $\mathrm{Z}$ metodologického hlediska se jednalo o tzv. záměrný výběr. Data narození jednotlivých tenistů byla získána $\mathrm{z}$ oficiálních materiálů ITF, výzkumná data byla zpracována pomocí software Microsoft Excel. Osobní údaje byly zpracovány se souhlasem hráčů a pořádající organizace (ITF).

VÝSLEDKY: Testování hypotézy o významnosti rozdílů v rozložení četností mezi jednotlivými čtvrtletími (Q1-Q4) prokázalo statisticky významné rozdíly mezi Q1 a Q3, Q1 a Q4, Q2 a Q3 a Q2 a Q4, statisticky významný rozdíl byl zjištěn stejně v rozložení četností mezi prvním a druhým půlrokem. Na základě výsledků prezentovaného výzkumu lze u zkoumaného souboru juniorských tenistů považovat dopad „age effect“ za významný.

ZÁVĚRY: Výsledky analýzy výzkumných dat potvrzují závěry obdobných studií $\mathrm{v}$ jiných sportech a prokazují, že mezi elitními juniorskými tenisty, účastníky WJTF 2007-2011, mají výraznou převahu hráči narozeni v prvním a druhém čtvrtletí, tedy v první polovině roku. Z uvedených závěrů vyplývá pro sportovní praxi nutnost reflektovat vliv „,age effect“, protože zejména v juniorském věku může ovlivňovat sportovní výkonnost.

Klícová slova: datum narození, věk, tenis, muži, World Junior Tennis Finals. 